\title{
Self Image Orangtua dalam Memilih Lembaga Pendidikan Anak Usia Dini (Studi kasus pada PAUD Ar Ridho Kota Malang)
}

\author{
Cevyana Nafa Izzani, Umi Dayati, M. Ishom \\ Jurusan Pendidikan Luar Sekolah \\ Fakultas Ilmu Pendidikan Universitas Negeri Malang \\ E-mail: ncevyana@gmail.com
}

\begin{abstract}
This study aims to determine the parent's Self Image in the selection of audits. The research design used by the researcher is a case study design. This research was conducted in Tarbiyatul Athfal Ar Ridlo, Malang. The key informants selected by the researcher were 4 people, amely the principal and three student guardian. Data collection technique in this study was interviews, document study and observation. Data were analyzed qualitatively which includes the process of data reduction, data display, and verification. Data validity test is done by triangulation techniques and observation extension. The analysis shows that in the view of TA Ar Ridlo's parents are expensive schools that have good quality that raises socialite, fashionable and classy Self Image of parents
\end{abstract}

Keywords: Parents' Self Image, Childhood Education, classy

\begin{abstract}
Abstrak: Penelitian ini bertujuan untuk mengetahui Self Image orangtua dalam pemilihan lembaga PAUD. Rancangan penelitian yang digunakan oleh peneliti adalah rancangan penelitian studi kasus. Penelitian ini dilaksanakan di Tarbiyatul Athfal Ar Ridlo Kota Malang. Informan kunci penelitian ini sebanyak 4 orang, yaitu kepala sekolah dan tiga walimurid. Teknik pengumpulan data dalam penelitian ini adalah wawancara, studi dokumen dan observasi. Data dianalisis secara kualitatif yang meliputi proses reduksi data, display data, dan verifikasi. Uji keabsahan data dilakukan dengan teknik triangulasi dan perpanjangan pengamatan. Hasil analisis menunjukkan bahwa menurut pandangan orangtua TA Ar Ridlo merupakan sekolah mahal yang memiliki kualitas baik yang memunculkan Self Image sosialita, fashionable dan berkelas dari orangtua.
\end{abstract}

\section{Kata Kunci: Self Image Orangtua, Pendidikan Anak Usia Dini, berkelas}

\section{PENDAHULUAN}

Perkembangan yang pesat menjadikan PAUD sebagai disiplin ilmu yang multi dan interdisipliner. Artinya, suatu disiplin ilmu yang terdiri atas banyak ilmu yang saling terkait, seperti; ilmu pendidikan, ilmu psikologi perkembangan, ilmu biologi perkembangan, ilmu sosiologi, ilmu kesehatan, ilmu olahraga dan ilmu bidang studi. Menurut Maimunah (2010) Pendidikan Anak Usia Dini (PAUD) adalah jenjang pendidikan sebelum jenjang pendidikan dasar yang merupakan suatu upaya pembinaan yang ditujukan bagi anak sejak lahir sampai dengan usia enam tahun yang dilakukan melalui pemberian rangsangan pendidikan untuk membantu pertumbuhan dan perkembangan jasmani dan ruhani agar anak memiliki kesiapan dalam memasuki pendidikan lebih lanjut, yang diselenggarakan pada jalur formal, nonformal, dan informal.

Seiring dengan perkembangan zaman, kesadaran orangtua tentang pentingnya pendidikan anak sejak dini semakin meningkat. Apalagi bagi masyarakat yang hidup di lingkungan perkotaan. Sebagian orangtua sadar betul bahwa anak-anak saat ini berada pada usia kritis dimana anak dapat mudah menyerap stimulus yang diberikan lingkungan 
sekitarnya. Orangtua masa kini harus memiliki strategi khusus bagi masa depan anak. Tersedianya beberapa jenis dan model tempat pendidikan anak yang memiliki berbagai fasilitas unggulan memudahkan orang tua dalam memilih sekolah demi menunjang pertumbuhan dan perkembangan anak sejak dini.

Hal ini ditandai dengan banyaknya perhatian para orangtua dalam memilih pendidikan untuk anak usia dini. Bahkan menjadikan salah satu sekolah sebagai pilihan secara turun-temurun. Secara garis besar memilih sekolah yang baik memiliki beberapa kriteria, diantaranya adalah sekolah dengan gedung yang baik, memiliki fasilitas sarana dan prasarana pendukung yang memadai, pembelajaran yang sesuai dengan perkembangan anak dan menyenangkan, biaya sekolah yang terjangkau, tenaga pendidik yang kompeten, output yang dihasilkan, serta tempat yang aman dan nyaman bagi anak untuk belajar. Sebagaimana hasil penelitian yang menjelaskan dimensidimensi pelayanan prima lembaga PAUD diantaranya adalah ke-khasan, kepercayaan, kenyamanan, harapan, dan keterjangkauan (Wahyuni, 2019:11). Dimensi inilah yang menjadi faktor pendorong dipilihnya sebuah lembaga PAUD oleh masyarakat.

Orangtua memiliki peran yang dominan dalam pendidikan anak, karena orangtua merupakan orang yang paling mengerti kebutuhan pendidikan anak dan serta kebutuhan perkembangan anak. Tugas dari orangtua mengarahkan anaknya untuk memilih sekolah yang baik dan sesuai dengan tahap perkembangan anak. Arahan orangtua juga berfungsi untuk memberikan penilaian terhadap sekolah yang dipilih. Hal ini agar orangtua tidak salah memilihkan sekolah dan anak tidak tertekan dengan arahan orangtua. Pengaruh orangtua tersebut bersumber dari faktor penggerak orangtua untuk memilih sekolah anak.

Orangtua sebagai pusat figur dalam interaksinya dengan anak sehingga memiliki kedudukan strategis dan bertanggungjawab penuh dalam memberikan dorongan pada program pendidikan anak. Menurut Schunk (2012:434) para orang tua sebenarnya memiliki banyak cara untuk dapat melibatkan diri dalam pendidikan anakanak di sekolah. Diantaranya adalah keterlibatan orangtua dalam memilihkan sekolah anaknya. Pemilihan sekolah biasanya terkait dengan kedudukan atau status orang tua di masyarakat. Kedudukan diartikan sebagai tempat atau posisi dalam suatu kelompok sosial (Soekanto, 2006:210). Kedudukan tersebut membuat manusia memiliki harga diri yang tinggi dalam hidup bermasyarakat termasuk pada pemilihan sekolah. Semakin tinggi kualitas sekolah tersebut semakin tinggi pula rasa kebanggaan dan harga diri orangtua karena merasa anak mereka sekolah di tempat yang bagus dan berkualitas.

Secara umum Tarbiyatul Aulad Ar Ridlo atau lebih dikenal TA Ar-Ridlo merupakan salah satu sekolah yang bagus di daerah perkotaan Kota Malang. Lembaga ini memiliki tempat yang strategis karena jauh dari keramaian lalu lintas jalan raya, jumlah siswa pun banyak. Mayoritas orangtua siswa adalah orang berada, dengan begitu apakah dengan anaknya bersekolah di TA Ar-Ridlo dapat menjadikan orangtua bangga dan dapat membentuk Self Image tersendiri. Berdasarkan pemaparan tersebut, maka perlu dikaji lebih mendalam bagaimana Self Image orang tua dalam pemilihan lembaga pendidikan anak usia dini bagi 
anaknya. Tujuan dari penelitian ini adalah untuk mendeskripsikan bagaimana pandangan orangtua tentang TA ARRIDLO dan mendeskripsikan Self Image orangtua di TA Ar Ridlo Kota Malang.

\section{METODE}

Penelitian ini menggunakan pendekatan penelitian kualitatif dengan rancangan studi kasus. Rancangan penelitian ini digunakan karena peneliti ingin mengetahui dan mencoba menganalisis serta mendiskripsikan suatu kasus atau permasalahan yang ada pada suatu konteks permasalahan yang terjadi di TA Ar Ridlo. Jawaban yang ingin diperoleh melalui penelitian ini adalah gambaran secara komprehensif tentang Self Image atau citra diri orangtua atau walimurid dalam pemilihan pendidikan anak usia dini. Secara spesifik penelitian ini akan menjelaskan bagaimana pandangan orangtua tentang sekolah anak dan bagaimana sekolah yang bagus juga meningkatkan Self Image orangtua dari berbagai sisi. Pemilihan TA Ar Ridlo sebagai lokasi penelitian didsarkan pada pertimbangan bahwa TA Ar Ridlo adalah sekolah Islam yang memiliki jumlah banyak dan banyak yang berasal dari berbagai daerah. Orangtua yang tinggal di daerah perkotaan yang jaraknya cukup jauh dari TA Ar Ridlo tetap memilih TA Ar Ridlo sebagai tempat sekolah anaknya.

Data yang dikumpulkan dari para informan kunci yang berperan sebagai sumber data penelitian. Informan yang dipilih dalam penelitian ini adalah satu kepala sekolah TA Ar Ridlo dan tiga walimurid. Selain wawancara teknik pengumpulan data yang digunakan dalam penelitian ini adalah observasi dan studi dokumen. Data yang telah terkumpul dianalisis secara kualitatif yang meliputi tahapan reduksi data, display data, dan verifikasi atau pengambilan keputusan. Keabsahan temuan penelitian diuji dengan teknik triangulasi dan perpanjangan pengamatan.

\section{HASIL}

\section{Pandangan Orangtua Tentang Lembaga TA Ar Ridlo}

TA Ar Ridlo menjadi salah satu pilihan masyarakat untuk menyekolahkan anak usia dini, seperti yang dikatakan oleh Kepala sekolah bahwa TA Ar Ridlo adalah lembaga pendidikan yang memberikan pelayanan kepada seluruh lapisan masyarakat tidak hanya kalangan menengah ke atas saja. Lapisan masyarakat menengah kebawah pun bisa mendapatkan layanan pendidikan terbaik dari lembaga. Layanan di TA Ar Ridlo menjadi pertimbangan bagi orangtua dalam menentukan lembaga pendidikan anak. Masyarakat menilai bahwa TA Ar Ridlo menjadi salah satu lembaga PAUD favorit yang mendapatkan incaran orangtua. Masyarakat khususnya orangtua memiliki kriteria PAUD untuk anaknya dan memilih salah satu sekolah untuk anak mereka secara matang dan alasannya pun beragam. Namun lembaga TA Ar Ridlo di mata walimurid AR Ridlo memiliki pandangan tersendiri, sebagaimana penjelasan berikut. Pertama TA Ar Ridlo dipandang oleh orangtua sebagai sekolah mahal Ar Ridlo termasuk kategori sekolah dengan biaya yang cukup besar di sekitar, namun bukan menjadi masalah bagi walimurid. Kedua, TA Ar Ridlo dinilai sebagai lembaga PAUD yang berkualitas karena lembaga ini menerapkan system pembelajaran yang sesuai dengan perkembangan anak. Kualitas lembaga ini juga ditunjukkan oleh kualitas pendidiknya. Pendidik memiliki kompetensi yang baik sehingga anak dapat 
belajar dengan baik, pendidik mendorong anak untuk belajar mengambangkan potensi. Pendidik juga dapat membina anak dalam proses pembelajaran sehingga anak tidak merasa bosan dan selalu tertarik dengan pembelajaran yang diajarkan. Menurut para walimurid pembelajaran di Ar Ridlo sudah baik apalagi sekolah ini berbasis Islam, jadi Ar Ridlo mengajarkan dasar dasar agama kepada anak dengan telaten. Lembaga juga membangun nilainilai karakter religious melalui kegiatankegiatan pembiasaan, seperti sholat berjamaah, berdoa, membaca asmaul husna dan membiasakan untuk berinfaq. Kualitas TA Ar Ridlo juga ditunjukkan oleh fasilitas dan sarana prasarana yang dimiliki lembaga. Fasilitas di dalam sekolah Ar Ridlo memiliki nilai baik di mata orangtua karena dengan adanya fasilitas yang ada sangat menunjang pembelajaran anak-anak.

\section{Self Image Orangtua dalam Memilih TA Ar Ridlo}

Pemilihan sekolah tidak lepas dari campur tangan orangtua, apalagi pada masa usia dini keinginan orangtua memilih PAUD berkualitas sangat umum terjadi. Lembaga PAUD bergengsi menjadi incaran orangtua, karena semakin bagus sekolah semakin besar juga rasa kebanggan diri dan dapat membuat citra diri tinggi. Pemilihan lembaga TA Ar Ridlo sebagai tempat sekolah anaknya memberikan eksistensi tersendiri bagi orangtua. Eksistensi orangtua diperlihatkan dalam bentuk citra diri dimana orangtua mengembangkan penilaian terhadap dirinya. Hal ini terutama terjadi pada walimurid dari kalangan menengah ke atas. Orangtua seringkali melakukan interaksi bersamasama dengan para orang tua lainnya. Para orangtua walimurid membentuk perkumpulan atau paguyuban yang dikenal dengan sosialita. Perkumpulan tersebut bisa menjadi ajang bagi orangtua untuk mencari perhatian bahkan memperlihatkan siapa dirinya dari berbagai aspek. Perkumpulan sangat mempengaruhi orang dalam bergaul, pada walimurid Ar Ridlo bukan hanya perkumpulan paguyuban kelas saja namun ada beberapa walimurid yang membuat perkumpulan atau genk sendiri di luar urusan sekolah, dengan beberapa orang yang memiliki hobi yang sama. Sosialita tidak selalu memiliki makna jelak yang hanya menghabiskan uang untuk kegiatan elite namun sosialita walimurid TA Ar Ridlo tetap aktif dalam kegiatan dan tidak merugikan orang lain.

Bentuk kedua dari Self Image orang tua adalah penampilan. Menurut walimurid penampilan itu sangat penting karena penampilan bisa menunjukkan siapa dirinya. Bahkan tidak hanya penampilan dari orangtua. penampilan anak-anak pun dibuat terlihat menarik agar terlihat menonjol dari teman-temannya. Perilaku orangtua dalam menonjolkan penampilan ini menjadi nilai sendiri bagi orangtua walimurid. Penampilan yang fashionable dan menarik menjadi Self Image orangtua walimurid. Self Image ketiga yang dimiliki orang tua dalam memilih TA Ar Ridlo adalah penilaian bahwa dirinya merupakan keluarga berkelas. Para orangtua menilai bahwa dengan menyekolahkan anaknya di TA Ar Ridlo maka akan memperoleh penilaian sebagai keluarga berkelas, yaitu keluarga yang harmonis, berpendidikan, dan mapan. Informan penelitian menyatakan bahwa keluarga yang dimilikinya adalah keluarga yang harmonis, memiliki keluarga utuh ayah ibu dan anak keluarga yang merupakan keluarga milenial dengan pengasuhan 
modern dan menciptakan kasih sayang di dalamnya. Sebagian besar orangtua menjadi bagian dari keluarga yang berpendidikan tinggi dan menginginkan hal serupa juga kepada anaknya. Ini yang menjadi salah satu alasan orangtua menyekolahkan anak sejak usia dini agar mental mandiri dan bertanggung jawab juga tertanam dalam diri anak. Walimurid TA Ar Ridlo adalah keluarga mapan, dengan penghasilan orangtua yang baik dan memiliki fasilitas rumah yang nyaman bagi keluarga.

\section{PEMBAHASAN}

\section{Pandangan Orangtua Tentang TA Ar Ridlo}

Menurut orangtua TA Ar Ridlo adalah sekolah dengan biaya yang cukup besar namun biaya yang dikeluarkan bukan menjadi sebuah permasalahan karena ada imbal balik yang didapatkan. Motivasi orang tua menyekolahkan anaknya salah satunya adalah adanya kesadaran akan pentingnya Pendidikan Anak Usia Dini dan kualitas sekolah yang baik (Saputri, 2016). Pendidikan yang berkualitas dimata orangtua memiliki daya tarik yang kuat, orangtua akan selalu memburu pendidikan yang terbaik untuk anak seperti hasil temuan lapangan bahwa TA Ar Ridlo menjadi pilihan orangtua karena memiliki kualitas yang sesuai dengan keinginan orangtua, Hal tersebut senada dengan teori perilaku konsumen yang diungkapkan oleh Kotler (2005) dalam buku perilaku konsumen karya Etta Mamang Sangadji merumuskan bahwa kualitas merupakan suatu kondisi dinamis yang berhubungan dengan produk, jasa, manusia, proses, dan lingkungan yang memenuhi atau melebihi harapan. Temuan di lapangan menyatakan bahwa orangtua atau walimurid TA Ar Ridlo berpendapat bahwa pendidik atau guru di sekolah ini adalah pendidik yang kreatif yang mampu mengelola kelas dengan baik sehingga anak tidak bosan dalam proses pembelajaran. Para walimurid juga mengatakan bahwa guru mempunyai kesabaran dan ketelatenan dalam mengajar sehingga mampu mengarahkan anak didik dengan baik. Seiring dengan hal tersebut, lembaga pendidikan anak usia dini sebagai sarana bagi pengembangan kreativitas sekaligus pembelajaran kritis bagi anak usia dini yang tidak akan berfungsi optimal apabila guru sebagai seorang pendidik tidak memiliki komitmen, dedikasi, kesabaran, serta tanggung jawab untuk mewujudkan proses pembelajaran dalam situasi pendidikan yang menyenangkan, tenang dan kreatif. Seperti yang diungkapkan oleh Nanang Fathurrahman (2008) bahwa mendidik itu harus dilakukan dengan cinta, yaitu mendidik dengan modal emosi positif yang berarti bahwa dalam kondisi diri yang sadar. Yang dimaksud keadaan diri yang sadar adalah kondisi perasaan nyaman atau tidak dalam keadaan tertekan, selalu riang dan terlibat dengan materi yang diajarkan. Diri yang sadar juga diartikan sebagai suatau keadaan yang senantiasa menampilkan semangat dan gairah dalam mengajar dan secara aktif dan atrkatif memanifestasikan dalam tindakan.

Temuan hasil analisis di lapangan menyatakan bahwa pembelajaran pada TA Ar Ridlo tidak hanya sekedar bermain yang tidak memiliki makna tapi bermain yang memiliki makna pembelajaran untuk tumbuh kembang anak yang sehingga dalam pembelajaran anak tidak merasa bosan. Tentu saja pembelajaran yang harus diberikan dalam meningkatkan potensi anak pun harus sesuai dengan umur anak 
dan hakikat anak, hakikat anak pada masa usia dini adalah bermain, jadi walaupun bermain tetapi memiliki makna edukasi yang baik seperti pada salah satu fungsi pendidikan anak usia dini, yaitu fungsi bermain yang menurut Diana (2012) peranan pendidikan anak usia dini adalah memberikan kesempatan secara aktif kepada anak untuk bermain dan terlibat dalam permainan. Bermain merupakan hak setiap anak. Melalui bermain anak menjadi senang dan gembira mengembangkan berbagai potensi yang dimilikinya. Sebagai sekolah berbasis Islam TA Ar Ridlo selalu berupaya menjadikan sistem pembelajaran agama menjadi nomer satu, karena menurut walimurid ketika agamanya baik berarti pondasinya kuat dan kebaikan yang lain akan mengikuti. Sebagai sekolah berbasis Islam TA Ar Ridlo tidak hanya mengajarkan dasardasar agama namun berbagai hal lain seperti sosial seperti membantu dan berbagi dengan sesama, nilai kesopanan pembelajaran di dalamnya sesuai dengan tujuan pendidikan Raudatul Athfal menurut Ditjen Bimbagais (1987:54) adalah membekali anak dengan dasar keimanan dan ketakwaan, meletakkan dasar-dasar perkembangan sikap, pengetahuan, keterampilan, dan daya cipta. Pendidikan anak usia dini juga memberikan bekal kemampuan dasar kepada anak untuk memasuki sekolah dasar serta membekali anak untuk mengembangkan diri sesuai prinsip pendidikan anak usia dini dan pendidikan seumur hidup.

Dari temuan hasil observasi di lapangan dalam melaksanakan kegiatan pembelajaran, guru memerlukan sarana yang dapat mendukung kinerja agar pembelajaran dapat berjalan menarik. Dari hasil wawancara dengan walimurid diperoleh pendapat bahwa para orang tua setuju dengan adanya dukungan sarana pembelajaran yang memadai, dapat membantu guru dalam melakukan pembelajaran sehingga guru tidak hanya menyampaikan secara lisan tetapi juga bisa memanfaatkan alat belajar sesuai dengan sarana dan prasarana belajar yang disediakan sekolah. Bahkan halaman sekolah yang lapang pun dapat menjadi fasilitas yang bermanfaat, sebagaimana hasil observasi dan wawancara di lapangan bahwa halaman sekolah di TA Ar Ridlo juga rutin dimanfaatkan untuk kegiatan pembelajaran anak-anak. Hal tersebut di atas sejalan dengan pernyataan dari Mulyasa (2004:17) bahwa sarana pendidikan merupakan perangkat yang secara langsung dimanfaatkan untuk menunjang proses pendidikan, seperti gedung, ruangan kelas, perangkat meja kursi, serta alat-alat dan media pembelajaran. Sedangkan yang dimaksud dengan prasarana pendidikan merupakan fasilitas belajar yang secara tidak langsung menunjang proses pendidikan misalnya kebun, halaman, taman sekolah, jalan menuju sekolah.

\section{Self Image Orangtua TA Ar Ridlo}

Orangtua sebagai pusat figur dalam interaksinya dengan anak sehingga memiiliki kedudukan strategis dan bertanggungjawab penuh dalam memberikan dorongan pada program pendidikan anak. Menurut Schunk (2012:434) ada banyak cara para orangtua dapat melibatkan diri dalam pendidikan anak-anak mereka di sekolah. Hidup dalam masyarakat yang menjadi unsurunsur dalam lapisan masyarakat adalah kedudukan (status). Kedudukan (status) diartikan sebagai tempat atau posisi dalam suatu kelompok sosial (Soekanto, 
2006:210). Kedudukan tersebut membuat manusia memiliki harga diri yang tinggi dalam hidup bermasyarat termasuk pada pemilihan sekolah. Karena menurut para walimurid dari hasil wawancara mereka beranggapan semakain bagus sekolah semakin besar juga rasa kebanggaan mereka, sehingga timbul berbagai sisi citra diri karena ingin menyamakan kedudukan dengan yang lain. Temuan di lapangan menyatakan tentang Self Image orang tua ketika berada pada lingkup sekolah yang dapat dipandang secara langsung adalah penampilan, penampilan yang baik menjadi keharusan bagi orangtua atau walimurid karena dari penampilan seseorang dapat dihargai dan menunjukkan siapa diri mereka. Hal tersebut dikuatkan oleh Jersild tentang aspek pengukuran Self Image salah satunya memang dari segi penampilan, karena memang yang paling gampang dilihat dan dinilai, Pengukuran aspek Self Image dari Jersild (1963), yaitu perceptual component, Komponen ini merupakan penilaian yang dimiliki seseorang mengenai penampilan dirinya, yaitu segala hal yang meliputi keadaan fisik seseorang. Komponen ini disebut juga dengan aspek fisik dari self-image. Temuan hasil lapangan tentang Self Image orangtua dari segi penampilan diperkuat oleh dua dari empat faktor mempengaruhi Self Image menurut Mappiare (1982) adalah (1) penampilan menyeluruh, fisik dan psikis mempengaruhui pembentukan pribadi. Remaja senantiasa membandingkan keadaan fisiknya dengan teman-teman sebayanya. Perbedaan keadaan fisik dengan teman sebaya dapat menimbulkan perasaan malu dan rendah diri, (2) Pakaian dan perhiasan adalah standar lain bagi remaja. Keadaan pakaian yang tidak memuaskan seringkali membuat mereka menghindarkan diri dari pergaulan kelompok teman sebaya atau peer group.

Dalam perkumpulan walimurid TA Ar Ridlo terdapat paguyuban walimurid dari masing-masing kelas, paguyuban ini menggawangi segala kegiatan yang melibatkan orangtua, seperti rekreasi. Dalam paguyuban tersebut terdapat pengurus tetap seperti ketua, sekertaris, bendahara yang dipilih dari kalangan orang tua yang bisa mengabdi untuk tugas itu Suatu kebanggaan tersendiri menjadi ketua paguyuban kata salah satu ketua paguyuban walimurid karena ketika dipercaya menjadi ketua paguyuban berarti dirinya merasa orang pilihan yang bisa mengemban tugas tersebut. Pendapat tersebuat dikuatkan oleh Jersild (1963) tentang pengkuran aspek Self Image, salah satunya adalah conceptual component, yaitu konsepsi seseorang mengenai karakteristik dirinya, seperti kemampuan atau kelebihan, serta kekurangan atau keterbatasan dirinya. Komponen ini disebut juga dengan aspek psikologis dari Self Image. Selain dalam perkumpulan paguyuban dalam sekolah, beberapa orang tua mengaku membentuk sebuah genk atau perkumpulan sendiri yang dirasa beberapa orang memiliki selera yang sama dan membentuk kegiatan-kegiatan lain pribadi seperti arisan. Beberapa orang tua yang tergabung dalam genk tersebut merasa senang karena bisa berkumpul dengan orang-orang yang menyenangkan dan modern. Kesamaan rasa tersebut hingga membentuk sebuah perkumpulan sendiri yang menurut Jersild (1963), Self Image juga dipengaruhi oleh bagaimana penerimaan dari teman sebaya. Syarat adanya penerimaan dari teman sebaya selama masa remaja adalah penampilan fisik yang tidak berbeda dari orang lain. Temuan hasil analisis di lapangan dapat 
diketahui bahwa informan yang di wawancarai oleh peneliti adalah informan yang memiliki keluarga utuh, beranggotakan ayah ibu dan anak. Sebagian besar walimurid memiliki komunikasi yang baik antar anggota keluarga. Para informan menyadari bahwa kelurga merupakan bagian penting dalam kehidupan apalagi ketika kelurga itu memiliki anak, anak menjadi fokus penting oleh ayah dan ibu agar menjadi generasi yang membanggakan, dengan begitu Keadaan keluarga yang harmonis dan rukun sangat mempengaruhi prestasi belajar anak di sekolah, terjalin komunikasi yang baik antara ibu ayah dan anak memberi kan energi positif dalam keluarga.

Temuan lapangan dari Walimurid TA Ar Ridlo menyatakan jika berani banyak uang berani juga memilih sekolah yang bagus bahkan bergengsi seperti TA Ar Ridlo ini, karena pendidikan anak pada masa usia dini peran orangtua sangat banyak dibutuhkan. Dan bagi orangtua yang memiliki ekonomi tinggi bukan masalah tentang mahalnya biaya pendidikan. Informan juga memberi informasi status pendidikan terakhir. Orang tua juga sepakat bahwa sebagai orang yang berpendidikan tentunya dapat mendidik dengan baik. Lingkungan tinggal bahkan keluarga yang memiliki anak usia dini semua bersekolah, dengan begitu malu jika anak dari kecil tidak bersekolah.

Dengan begitu dapat dipahamai bahwa Self Image orangtua memilih pendidikan usia dini dari sisi keadaan keluarga yaitu ekonomi keluarga sangat mempengaruhi karena pada jaman sekarang pendidikan anak usia dini sangat marak dengan berbagai sistem yang menarik dan menyenangkan membuat orangtua harus selektif dalam pemilihan sekolah untuk anaknya, namun jika keadaan keluarga memiliki ekonomi tinggi biaya sekolah bukan lagi menjadi masalah dan dimana lingkungan tempat tinggal yang notabene semua anak usia dini bersekolah menjadi dorongan untuk orangtua dalam menyekolahkan anaknya. Dan ketika walimurid menyekolahkan anaknya di tempat yang bagus seperti Ar Ridlo ini, status sosial menjadi sorotan para walimurid lain sehingga menimbulkan image-image tertentu pada sesorang.

\section{SIMPULAN}

Pandangan orangtua tentang TA Ar Ridlo adalah sekolah berbasis Islam yang termasuk memiliki biaya yang besar namun bagus di kota Malang, mahal bukan menjadi masalah ketika orangtua merasa mendapatakan fasilitas yang sesuai dengan apa yang telah dikeluarkan. terlihat dari beberapa sudut pandang ketika walimurid berbicara bahwa TA Ar Ridlo adalah sekolah yang berkualitas yang dikemukakan oleh walimurid yaitu (1) pendidik, pendidik sekolah ini memiliki kompetensi yang baik, selain sabar dalam mengajar anak-anak , juga mampu memberikan energi positif sehingga anakanak bersemangat dalam bersekolah dan dapat menguasai kelas dengan baik sehingga anak-anak tidak bosan dalam proses pembelajaran (2) pembelajaran, sistem pembelajarn di TA Ar Ridlo juga bagus dan jelas memiliki konsep yang bagus sehingga anak-anak tertarik dalam mengikuti setiap pembelajarannya, apalagi dengan sekolah berbasis Islam Ar Ridlo mampu memberikan dasar-dasar agama yang baik kepada anak sehingga anak pun dapat mengikuti nya dengan baik di rumah (3) lingkungan dan fasilitas, menurut pandangan walimurid Ar Ridlo lingkungan 
di sekolah ini nyaman memiliki halaman yang luas dan udara yang sejuk, dalam fasilitas pun mumpuni sesuai dengan pembelajaran yang ada.

Self Image orangtua dalam pemilihan sekolah untuk anak, dalam konteks ini yaitu pendidikan anak usia dini TA Ar Ridlo Kota Malang, yaitu TA Ar Ridlo termasuk sekolah anak usia dini berbasis Islam yang bagus di kota malang , sehingga orangtua dalam memilihkan sekolah ini kepada anak juga memiliki rasa kebanggaan tersendiri karena anak-anak mereka bersekolah di tempat yang bagus. Status sosial juga berpengaruh pada pemilihan sekolah dan pembentukan Self Image yang dapat dilihat dari keadaan keluarga, penampilan dan perkumpulan Sehingga pada lingkup sekolah eksistensi orangtua sangatlah berpengaruh untuk unjuk diri. (1) penampilan sangat penting karena penampilan adalah bentuk langsung yang dapat dinilai orang lain, (2) perkumpulan juga mempengaruhi seseorang dalam bergaul, membuat walimurid ingin menjadi yang tereksis dalam perkumpulan tersebut (3) keadaan keluarga yang berkelas dan cukup dari sisi ekonomi membuat orang semakin mudah untuk penunjang pembentukan Self Image.

\section{DAFTAR RUJUKAN}

Ditjen Bimbagais. 1987. Informasi Direktorat Jendral Pembinaan Kelembagaan Agama Islam. Jakarta:
Direktorat Jendral Pembinaan

Kelembagaan Agama Islam

Fathurrahman, Nanang. 2008. Teaching With Love: Pendekatan Cinta dan Akhlak Mulia Dalam Pembelajaran. Jakarta: Lendean Pustaka.

Jersild, A.T. 1963. The Psychology of Adolescent. New York: The Mc Millan.

Kotler, Philip. 2005. Manajamen Pemasaran, Jilid 1 dan 2. Jakarta: PT. Indeks Kelompok Gramedia.

Maemunah, Hasan. 2010. PAUD (Pendidikan Anak Usia Dini), Cet II. Yogyakarta: Diva Press.

Mappiare. 1982. Psikologi Remaja. Surabaya: Usaha Nasional.

Mulyasa. 2004. Manajemen Berbasis Sekolah, Konsep, Strategi dan Implementasi. Bandung: PT Remaja Rosdakarya.

Saputri. 2016. Motivasi Orangtua Dalam Memilih Paud Ditinjau Dari Profil Lembaga Pendidikan. Skripsi Jurusan Pendididkan Guru Pendidikan Anak Usia Dini Universitas Negeri Semarang.

Schunk, Dale. H. 2012. Learning Theories: An Educational Perspectives, 6th Edition. New York: Pearson Education Inc.

Soekanto, Soerjono, 2006. Sosiologi Suatu Pengantar. Jakarta: PT. Raja Grafindo Persada.

Wahyuni. 2019. Excellent Service Dimension from the Early Childhood Education Institute. Jurnal Nonformal education, 5(2), 1-12. Dari: Universitas Negeri Semarang. 